\title{
Healthcare Needs of the Elderly People over 85 Years Living Alone on the Island Area in Japan: A Descriptive Study
}

\author{
Osamu Hiramitsu' ${ }^{1}$, Michiko Moriyama ${ }^{1 *}$, Kanae Osaki ${ }^{1}$, Ritsuko Sakamoto ${ }^{1}$, Megumi Sakamoto ${ }^{1}$, \\ Shoko Maeno², Hidemi Sasaki ${ }^{3}$, Katm Ehsanul Huq1, Md Moshiur Rahman' \\ ${ }^{1}$ Graduate School of Biomedical \& Health Sciences, Hiroshima University, Hiroshima, Japan \\ ${ }^{2}$ Department of Health and Social Welfare, Kure City Municipality, Hiroshima, Japan \\ ${ }^{3}$ Graduate School of Nursing, Hiroshima Bunka Gakuen University, Hiroshima, Japan \\ Email: *morimich@hiroshima-u.ac.jp
}

How to cite this paper: Hiramitsu, O., Moriyama, M., Osaki, K., Sakamoto, R., Sakamoto, M., Maeno, S., Sasaki, H., Huq, K.E. and Rahman, M.M. (2018) Healthcare Needs of the Elderly People over 85 Years Living Alone on the Island Area in Japan: A Descriptive Study. Health, 10, 516-530. https://doi.org/10.4236/health.2018.104041

Received: March 21, 2018

Accepted: April 27, 2018

Published: April 30, 2018

Copyright $\odot 2018$ by authors and Scientific Research Publishing Inc. This work is licensed under the Creative Commons Attribution International License (CC BY 4.0).

http://creativecommons.org/licenses/by/4.0/

(c) (i) Open Access

\begin{abstract}
Background: Japan has the highest aging people accounting 33.8 million with the rate of $26.7 \%$ in 2015 . Although, public long-term care insurance services support people age 40 years and above, most of the users are 85 years and over due to their more vulnerability for getting sick. This study describes the physical, mental and social status of the elderly people aged 85 years and over, who were living alone at home. Method: A cross-sectional study was conducted between November 2016 and March 2017 in the island of Kure city, Hiroshima, Japan. A structured questionnaire and scales were used for data collection and documentation of physical measurements. Descriptive analysis was used. Result: A total of 190 subjects were participated, and the data were analyzed. The age range of the subjects was 85 to 98 years, and $68.4 \%$ of them were 85 to 89 years old. Male and female ratio was $21.6 \%$ vs $78.4 \%$. Subjects of $17.4 \%$ continued their occupation at the time of the study period and most of them involved in agricultural work (93.9\%). A certain percentage of the subjects had abnormal physical, mental and social difficulties and need additional support from family, friends, relatives, and community. Conclusion: Early detection and intervention such as disease management, nutritional support, and human support are required. The findings suggested policy makers to predict the burden and provide necessary care for these elderly people. It is necessary to aware family, friends, relatives, community and government supporting staff to provide information on correct recognition and usages of long-term care insurance services for these elder people.
\end{abstract}

\section{Keywords}

Elderly, Living Alone, Long-Term Care Insurance, Japan 


\section{Introduction}

The population in Japan is declining due to the constrictive pattern of birth rate and turning into super-aged society since 2007. The elderly people aged 65 years or older as of 2015 were 33.8 million and the aging rate was $26.7 \%$, the highest in the world [1]. In particular, over 75 years old elderly people, who are living alone, continue to grow that can affect the sustainability of the social security support system, which is becoming a major issue for the government [2]. Moreover, the "baby-boomer generation" will enter in late elderly aged 75 years and older in 2025 [3], which will be needed additional support through the comprehensive approach and service provision system (The Integrated Community Care System) provided by the national government.

According to the nationwide survey in 2012, 54.6\% of respondents aged 55 years and more, answered that they wish to die at home [4]; however, the death rate at home was only $12.8 \%$ [5], and it reflects a huge discrepancy. Currently, the usages of public long-term care insurance services for the elderly people aged 75 years and over are rapidly increasing. The age group of 85 years and over, who is more vulnerable for getting sick is receiving the services twice compare to the earlier age group (75 to 84 years) [6]. The prevalence rate of different diseases in this age group is also reported higher compared to other age groups [7]. The level of health condition and healthy feelings declined with age [4], and consequently increased the risk of death [8]. Declining the living functions is a risk factor for elderly people that can cause bedridden in association with homebound [9].

Kure City of Hiroshima Prefecture was the survey area that had aging rate age (65 years and over) of $33.5 \%$ at the end of March 2016, the highest among the municipalities of the same size. The aging rate of the center of Kure city was $24.4 \%$ compared to $59.7 \%$ in the island part, which showed the wide regional disparity [10]. In a survey of the aging people conducted by the Kure City in $2014,47.5 \%$ of elderly people responded that they would like to stay at home even if they become care needy situation in the future instead of clinic or hospital for their nursing care. However, the mortality rate at home was only $13.8 \%$ [11]. This is the reality in Kure city as many elderly people want to die at home, although finally they admitted in the hospital up to death. Therefore, the purpose of this research is to describe the comprehensive (physical, mental, and social) status of the elderly people aged 85 years and over for early detection and prevention of unplanned aggravation of conditions. This study findings will give the glimpse to policy makers about the necessary support of the elderly people while living alone at home.

\section{Methods}

\subsection{Subjects}

Subjects were residents of Kure city island area selected from the resident registry of Kure city municipal government in March 2016. Inclusion criteria were at 
the time of the survey: 1) aged 85 years and older and 2) lived alone at homes. Exclusion criteria were at the time of the survey: 1) hospitalized, 2) living in a nursing home, 3) absent for 3 consecutive home visits, 4) did not agree to participate and 5) died or moved or living with other persons.

\subsection{Research Design and Procedure}

A cross-sectional study was conducted from November 2016 to March 2017. The data were collected from the resident registry of Kure city municipal government, and 303 participants were identified as eligible. The Kure city informed the subjects to participate in this study. The subjects were requested to come to the nearest community center on a prescheduled day. The subjects who were not able to visit the center, afterward a home visit was conducted by the researchers. A structured questionnaire was used for data collection and documented the physical measurements.

\subsection{Questionnaire Items}

The components of the questionnaire were created by the researchers to describe subjects' basic attributes, physical condition including cognitive status, mental conditions, and social conditions with the reference of comprehensive geriatric assessment [12], and future thought of life. To describe physical and mental conditions, we used standardized scales as listed below. We also assessed physical conditions by the features of the physical measurement. The questionnaire was consisted of five main categories.

1) Socio-demographic characteristics including age, gender, and occupation at the time of the study.

2) Physical conditions: blood pressure, pulse, respiration, cognitive function assessed by Hasegawa's Dementia Scale-Revised (HDS-R) (Conducted only when declines in the activities of daily living (ADL) and cognitive reply), edema, Mini Nutritional Assessment-Short Form (MNA) [13], body mass index (BMI), appetite, dental condition, hearing and vision, frequencies of going out operationally categorized the subjects who did not go out at all or who did not go out within a week as "withdrawal", and the subjects who go out more than once a week as "not withdrawal" [14], walking state, pain, and history of medical illness and hospitalization. Physical status was evaluated by asking questions and physical examinations without any invasive procedures.

3) Mental condition: Subjective sense of well-being was measured by four-point Likert scale (healthy, somewhat healthy, somewhat unhealthy, and unhealthy), Personal Health Questionnaire 2 (PHQ2) [15] were used to assess the depression, anxiety, and worries.

4) Social condition: Type of residence, human support, support for meals and knowledge about the long-term care insurance system.

5) Future thoughts on life: Intention to use long-term care insurance service, thoughts of the end of life, preoccupied thoughts about dying, create a testa- 
mentary will, and a place to spend the end of life.

\subsection{Data Analysis}

Descriptive statistics were conducted for data analysis by using the software SPSS version 21.0.

\subsection{Ethical Consideration}

This research was approved by the Epidemiological Ethics Review Committee of Hiroshima University (No. E-530-1). The survey was conducted anonymously when subjects agreed to consent.

\section{Results}

\subsection{Participation (Figure 1)}

Out of 303 subjects, 190 subjects were enrolled, and data were analyzed. Totally

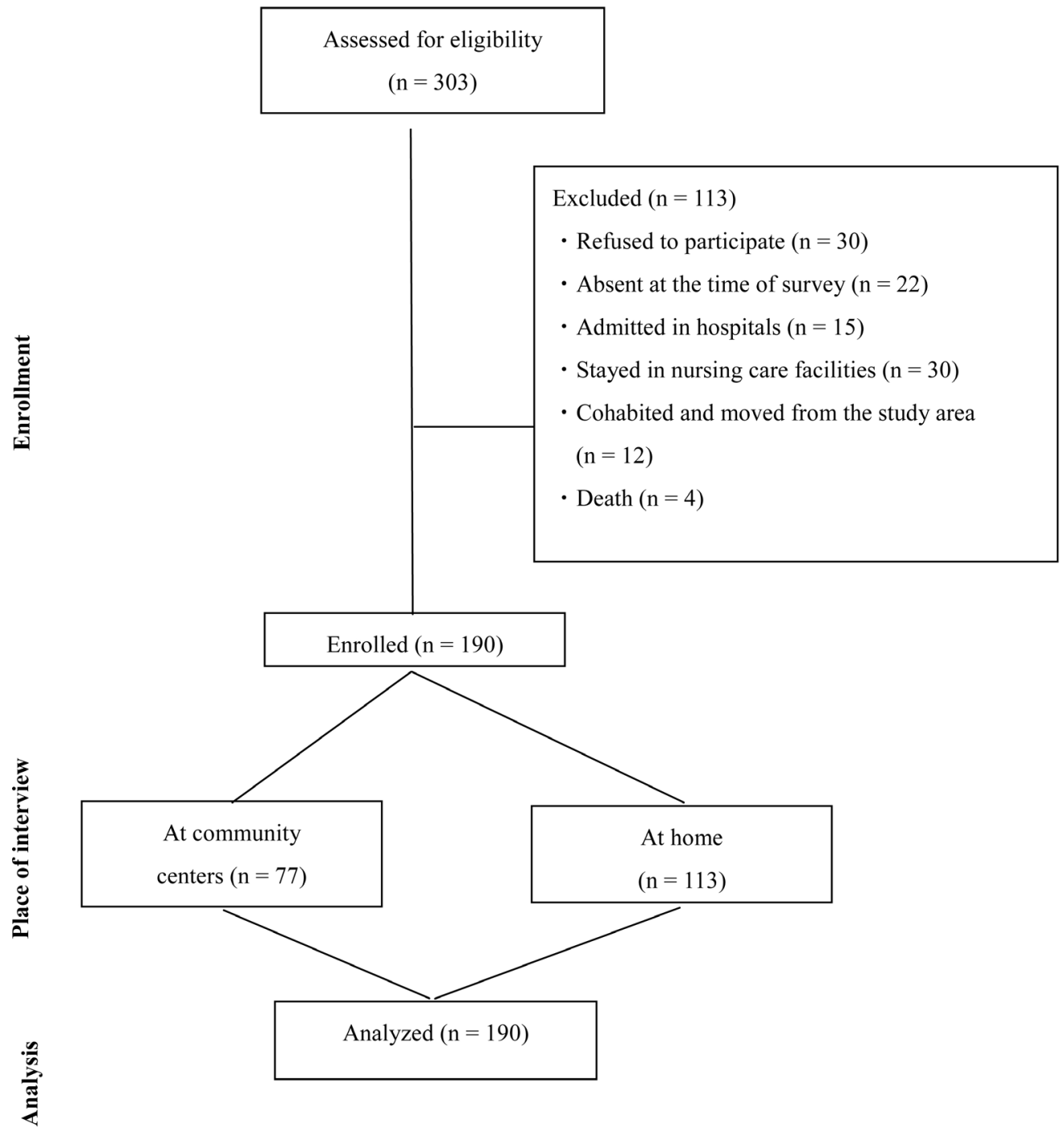

Figure 1. Consort flow chart for subject enrollment. 
113 subjects were excluded; 15 were hospitalized; 30 were at nursing homes; 12 moved to other places such as children's homes; 4 were dead; 22 were absent for 3 times during the survey; and 30 did not provide consent. Among the 190 subjects, 77 visited at the community centers, and remaining 113 were at home.

\subsection{Basic Attributes of the Subjects}

The age range of the subjects were from 85 to 98 years, and $68.4 \%$ of them were from 85 to 89 years old. Among them, $21.6 \%$ were male and $78.4 \%$ were female, and $17.4 \%$ continued their occupation at the study time, out of them mostly agriculture (93.9\%) (Table 1).

\subsection{The Physical, Mental and Social Condition of the Subjects}

1) Physical Conditions: (Table 2)

Out of $189,49.7 \%$ had high blood pressure, $18.9 \%$ arrhythmia and $3.4 \%$ tachypnea. Subjects of $5.9 \%$ cognitive function declined. Pedal edema $52.9 \%$, malnutrition and had risk of malnutrition $36.3 \%$ and low body weight was $11.3 \%$. There were $79.5 \%$ used dental prostheses, and $8.4 \%$ had no teeth or many teeth defects. Hearing and vision problem were $37.9 \%$ and $14.3 \%$, respectively. While walking, $61.6 \%$ needed assistive tools. Physical pain had $72.6 \%$ and history of medical illness, and hospitalization were $95.3 \%$.

2) Mental Conditions: (Table 3)

Table 1. Socio-demographic characteristics. $\mathrm{N}=190$

\begin{tabular}{|c|c|c|c|c|c|c|c|c|c|}
\hline \multirow[t]{2}{*}{ Age } & & \multicolumn{4}{|c|}{85 to 89} & \multicolumn{2}{|c|}{90 to 94} & \multicolumn{2}{|c|}{95 to 100} \\
\hline & & $\begin{array}{l}\text { Number } \\
\text { of people }\end{array}$ & $\%$ & $\begin{array}{l}\text { Number } \\
\text { of people }\end{array}$ & $\%$ & $\begin{array}{l}\text { Number } \\
\text { of people }\end{array}$ & $\%$ & $\begin{array}{l}\text { Number } \\
\text { of people }\end{array}$ & $\%$ \\
\hline \multirow[t]{3}{*}{ Sex } & Male & 41 & 21.6 & 30 & 15.8 & 11 & 5.8 & 0 & 0.0 \\
\hline & Female & 149 & 78.4 & 100 & 52.6 & 44 & 23.2 & 5 & 2.6 \\
\hline & & 190 & 100.0 & 130 & 68.4 & 55 & 29.0 & 5 & 2.6 \\
\hline \multirow[t]{3}{*}{ Job } & Yes & 33 & 17.4 & 26 & 13.7 & 7 & 3.7 & 0 & 0 \\
\hline & No & 157 & 82.6 & 104 & 54.7 & 48 & 25.3 & 5 & 2.6 \\
\hline & & 190 & 100.0 & 130 & 68.4 & 55 & 29.0 & 5 & 2.6 \\
\hline \multicolumn{2}{|c|}{$\begin{array}{l}\text { Previous job type } \\
\quad \text { (Top five) }\end{array}$} & 190 & & & & & & & \\
\hline \multicolumn{2}{|c|}{ Agriculture } & 112 & 58.9 & & & & & & \\
\hline \multicolumn{2}{|c|}{ Fisherman } & 23 & 12.1 & & & & & & \\
\hline \multicolumn{2}{|c|}{ Factory worker } & 16 & 8.4 & & & & & & \\
\hline \multicolumn{2}{|c|}{ Professional } & 14 & 7.4 & & & & & & \\
\hline \multicolumn{2}{|c|}{ Construction worker } & 9 & 4.7 & & & & & & \\
\hline \multicolumn{9}{|c|}{ Age range from 85 to 98 years } & \\
\hline
\end{tabular}


Table 2. Physical condition of the subjects. $\mathrm{N}=190$.

\begin{tabular}{|c|c|c|c|c|}
\hline Physical state & $\begin{array}{l}\text { Effective } \\
\text { reply }\end{array}$ & & $\begin{array}{l}\text { Number } \\
\text { of people }\end{array}$ & $\%$ \\
\hline \multirow[t]{3}{*}{ Blood pressure* } & 189 & I degree & 74 & 39.2 \\
\hline & & II degree & 15 & 7.9 \\
\hline & & III degree & 5 & 2.6 \\
\hline Pulse & 190 & Arrhythmia & 36 & 18.9 \\
\hline \multirow[t]{4}{*}{ (Breakdown) } & & $\begin{array}{l}\text { Pulse of rhythm } \\
\text { abnormalities }\end{array}$ & 14 & 7.4 \\
\hline & & Less than 60 beat $/ \mathrm{min}$ & 14 & 7.4 \\
\hline & & $\begin{array}{l}\text { Less than } 60 \text { beat } / \mathrm{min} \& \\
\text { rhythm abnormalities }\end{array}$ & 3 & 1.6 \\
\hline & & $\begin{array}{l}100 \text { beats } / \mathrm{min} \\
\text { or more }\end{array}$ & 5 & 2.6 \\
\hline Respiration & 179 & Tachypnea ( $\geq 25 / \mathrm{min})$ & 6 & 3.4 \\
\hline $\begin{array}{l}\text { Cognitive function } \\
\text { (HDS-R) }\end{array}$ & 16 & Decline $($ Score $\leq 20)$ & 11 & 68.8 \\
\hline Edema & 187 & Present & 99 & 52.9 \\
\hline \multirow[t]{2}{*}{$\begin{array}{c}\text { Mini Nutritional } \\
\text { Assessment }\left(\mathrm{MNA}^{\oplus}\right)\end{array}$} & 179 & Malnourished & 1 & 0.6 \\
\hline & & At risk of malnutrition & 64 & 35.8 \\
\hline BMI & 160 & $<18.5$ & 18 & 11.3 \\
\hline \multirow[t]{2}{*}{ Appetite } & 190 & Moderate decline & 17 & 8.9 \\
\hline & & Significant decline & 2 & 1.1 \\
\hline \multirow[t]{2}{*}{ Tooth condition } & 190 & Denture & 151 & 79.5 \\
\hline & & Severe defect & 16 & 8.4 \\
\hline Past medical history & 190 & Present & 181 & 95.3 \\
\hline \multirow[t]{6}{*}{ (Breakdown of the top six) } & & Hypertension & 80 & 44.2 \\
\hline & & Cataract & 47 & 26.0 \\
\hline & & Bone fracture & 37 & 20.4 \\
\hline & & Heart disease & 34 & 18.8 \\
\hline & & Dyslipidemia & 33 & 18.2 \\
\hline & & Tumor & 31 & 17.2 \\
\hline Hospitalization history & 190 & Present & 154 & 81.1 \\
\hline \multirow[t]{6}{*}{ (Breakdown of the top six) } & & Bone fracture & 33 & 21.4 \\
\hline & & Digestive diseases & 28 & 18.2 \\
\hline & & Cataract & 26 & 16.9 \\
\hline & & Cancer & 24 & 15.6 \\
\hline & & Cerebrovascular disease & 21 & 13.6 \\
\hline & & Trauma & 13 & 8.4 \\
\hline Hearing impairment & 190 & $\begin{array}{l}\text { Able to hear only } \\
\text { loud sounds }\end{array}$ & 72 & 37.9 \\
\hline
\end{tabular}




\section{Continued}

\begin{tabular}{|c|c|c|c|c|}
\hline Vision & 182 & $\begin{array}{l}\text { Not able to read } \\
\text { newspaper }\end{array}$ & 26 & 14.3 \\
\hline Walking condition & 190 & $\begin{array}{l}\text { Able to walk by using } \\
\text { auxiliary tools }\end{array}$ & 117 & 61.6 \\
\hline $\begin{array}{l}\text { Frequency of } \\
\text { going out }\end{array}$ & 188 & Didn't go out $>1$ week & 9 & 4.8 \\
\hline \multirow{6}{*}{$\begin{array}{l}\text { Thoughts on } \\
\text { going out }\end{array}$} & 187 & Feeling burden & 82 & 43.9 \\
\hline & & $\begin{array}{l}\text { Worried about physical } \\
\text { condition }\end{array}$ & 56 & 29.9 \\
\hline & & $\begin{array}{l}\text { Troublesome and } \\
\text { dislike }\end{array}$ & 16 & 8.6 \\
\hline & & $\begin{array}{c}\text { Transportation } \\
\text { inconvenient }\end{array}$ & 13 & 7.0 \\
\hline & & No purpose & 5 & 2.7 \\
\hline & & Economic burden & 2 & 1.1 \\
\hline Physical pain & 190 & Present & 138 & 72.6 \\
\hline \multirow[t]{2}{*}{ Site of pain } & 138 & Knee joint & 67 & 48.6 \\
\hline & & Low back pain & 59 & 42.8 \\
\hline
\end{tabular}

*Blood pressure: I degree (systolic 140 to $159 \mathrm{mmHg}$ and/or diastolic 90 to $99 \mathrm{mmHg}$ ), II degree (systolic 160 to $179 \mathrm{mmHg}$ and/or diastolic 100 to $109 \mathrm{mmHg}$ ), III degree (systolic $180 \mathrm{mmHg}$ or more and/or diastolic $110 \mathrm{mmHg}$ or more) (The Japanese Society of Hypertension Committee for guidelines for treatment of hypertension, 2014).

Table 3. Mental condition of the subjects. $\mathrm{N}=190$.

\begin{tabular}{|c|c|c|c|c|}
\hline $\begin{array}{l}\text { Mental condition } \\
\quad \text { (item) }\end{array}$ & Effective reply & & $\begin{array}{l}\text { Number } \\
\text { of people }\end{array}$ & $\%$ \\
\hline $\begin{array}{l}\text { Subjective sense of } \\
\text { well-being }\end{array}$ & 186 & Unhealthy & 29 & 15.6 \\
\hline $\begin{array}{l}\text { Depression trend } \\
\quad(\text { PHQ 2) }\end{array}$ & 187 & Yes $(>1$ item $)$ & 17 & 9.1 \\
\hline Anxiety and worries & 188 & Present & 106 & 56.4 \\
\hline \multirow[t]{9}{*}{ (Breakdown) } & & Own health & 54 & 50.9 \\
\hline & & $\begin{array}{c}\text { Accident \& falling } \\
\text { down }\end{array}$ & 35 & 33.0 \\
\hline & & Family health & 29 & 27.4 \\
\hline & & Disaster & 15 & 14.2 \\
\hline & & $\begin{array}{c}\text { Excretion of waste } \\
\text { on the way }\end{array}$ & 14 & 13.2 \\
\hline & & $\begin{array}{c}\text { Don't have } \\
\text { someone to take } \\
\text { care of }\end{array}$ & 6 & 5.7 \\
\hline & & $\begin{array}{c}\text { Place to live at the } \\
\text { end of life }\end{array}$ & 5 & 4.7 \\
\hline & & Lonely feeling & 17 & 16.0 \\
\hline & & Financial problem & 11 & 10.4 \\
\hline
\end{tabular}


Table 4. Social condition of the subjects. $\mathrm{N}=190$.

\begin{tabular}{|c|c|c|c|c|}
\hline Social condition & $\begin{array}{l}\text { Effective } \\
\text { reply }\end{array}$ & & $\begin{array}{l}\text { Number } \\
\text { of people }\end{array}$ & $\%$ \\
\hline Type of residence & 190 & Single-family house & 189 & 99.5 \\
\hline Consultation partner & 189 & Present & 184 & 97.4 \\
\hline \multirow[t]{11}{*}{ (Breakdown) } & & Children & 152 & 82.6 \\
\hline & & Relatives & 67 & 36.4 \\
\hline & & Primary care doctor & 63 & 34.2 \\
\hline & & Neighbors & 59 & 32.1 \\
\hline & & Friends & 44 & 23.9 \\
\hline & & District welfare officer & 41 & 22.3 \\
\hline & & Care Manager & 16 & 8.7 \\
\hline & & Acquaintances & 13 & 7.1 \\
\hline & & City office & 7 & 3.8 \\
\hline & & $\begin{array}{l}\text { Appointed regional } \\
\text { chairman }\end{array}$ & 3 & 1.6 \\
\hline & & $\begin{array}{c}\text { Integrated care } \\
\text { management Center }\end{array}$ & 3 & 0.5 \\
\hline Emergency contact person & 189 & No & 6 & 3.2 \\
\hline Support person in daily life & 190 & No & 49 & 25.8 \\
\hline \multirow[t]{2}{*}{ Cooking person } & 190 & Self + Others help & 20 & 10.5 \\
\hline & & Others help & 18 & 9.5 \\
\hline \multicolumn{5}{|l|}{ Long-term care insurance system } \\
\hline Knowledge of existence & 189 & Don't know & 47 & 24.9 \\
\hline The method of procedure & 189 & Don't know & 140 & 74.1 \\
\hline Services available in the region & 189 & Don't know & 107 & 56.6 \\
\hline
\end{tabular}

Subject of $15.6 \%$ reported unhealthy, 9.1\% had depressive illness, and $56.4 \%$ suffered from anxiety and worries.

3) Social Conditions: (Table 4)

Subjects of $99.5 \%$ lived in their own house, and $3.2 \%$ had no contact person during emergency. The subjects who did not receive daily support were $25.8 \%$.

\subsection{Subject's Knowledge about the Long-Term Care Insurance System}

Out of 190 subjects, 189 (98.9\%) were responded about the Long-Term Care Insurance System. Subjects of $24.9 \%$ had no knowledge about the existence, $74.1 \%$ did not know about the access, and 56.6\% did not know about the availability of the regional services of the long-term care insurance system (Table 4).

\subsection{The Results of the Future Thoughts about Their Life and Usages of Long-Term Care Insurance Service}

Subjects of $61.2 \%$ did not want to use long-term care insurance service; $89.5 \%$ wished to die without bothering anyone; $14.4 \%$ desired to receive highest satisfactory medical treatment, $31.0 \%$ wanted to receive palliative treatment for pain 
Table 5. Intention of the subjects. $\mathrm{N}=190$.

\begin{tabular}{|c|c|c|c|c|}
\hline $\begin{array}{l}\text { Future intention of life } \\
\text { about death }\end{array}$ & $\begin{array}{l}\text { Effective } \\
\text { reply }\end{array}$ & & $\begin{array}{l}\text { Number } \\
\text { of people }\end{array}$ & $\%$ \\
\hline $\begin{array}{l}\text { Intention to use long-term care } \\
\text { insurance services }\end{array}$ & 183 & Don't want & 112 & 61.2 \\
\hline $\begin{array}{l}\text { Living at home without using the } \\
\text { long-term care insurance services }\end{array}$ & 188 & Yes & 129 & 68.6 \\
\hline $\begin{array}{l}\text { Living at home with using long-term } \\
\text { care insurance services }\end{array}$ & 187 & Yes & 120 & 64.2 \\
\hline $\begin{array}{l}\text { Intention to move in the house for } \\
\text { senior citizen with services }\end{array}$ & 187 & Yes & 12 & 6.4 \\
\hline $\begin{array}{l}\text { Intention to move to a long-term care } \\
\text { facility since healthy condition }\end{array}$ & 188 & Yes & 9 & 4.8 \\
\hline $\begin{array}{l}\text { Intention to move to a long-term care } \\
\text { facility when become care needed }\end{array}$ & 184 & Yes & 66 & 35.9 \\
\hline Want to die without bothering anyone & 181 & Yes & 162 & 89.5 \\
\hline $\begin{array}{l}\text { Intended to receive highest satisfactory } \\
\text { medical treatment at the end of life }\end{array}$ & 174 & Yes & 25 & 14.4 \\
\hline $\begin{array}{l}\text { Intended to receive palliative care (e.g. } \\
\text { relieve pain) at the end of life (excluded } \\
\text { subjects who answered above) }\end{array}$ & 174 & Yes & 54 & 31.0 \\
\hline Natural Death without medical treatment & 174 & Yes & 78 & 44.8 \\
\hline $\begin{array}{l}\text { Spending rest of the life with } \\
\text { family and friends }\end{array}$ & 167 & Yes & 74 & 44.3 \\
\hline Expressing weakening features to others & 167 & No & 40 & 24.0 \\
\hline $\begin{array}{l}\text { In case of home death while living } \\
\text { alone, the police comes }\end{array}$ & 174 & Yes & 83 & 47.7 \\
\hline $\begin{array}{l}\text { Those who think that they cannot die in a } \\
\text { hospital unless they are visiting regularly } \\
\text { in a hospital }\end{array}$ & 168 & Yes & 49 & 29.2 \\
\hline Already prepared a will testament & 179 & Yes & 17 & 9.5 \\
\hline Would like to prepare a will testament & 178 & No & 143 & 80.3 \\
\hline \multirow[t]{5}{*}{ Place of spending the end of life } & 187 & Own home & 111 & 59.4 \\
\hline & & Hospital & 27 & 14.4 \\
\hline & & $\begin{array}{c}\text { Other } \\
\text { facilities }\end{array}$ & 8 & 4.3 \\
\hline & & Unknown & 34 & 18.2 \\
\hline & & Others & 7 & 3.7 \\
\hline
\end{tabular}

and suffering; $44.8 \%$ wished to follow the natural dying process without getting any medical treatment; $44.3 \%$ desired to spend rest of their life with families and friends. Regarding dying, $47.7 \%$ thought if they die alone at home, the police came for inspection, therefore, it was shame to die at home alone; $29.2 \%$ thought 
that they could not die in the hospital if they were not hospitalized early enough. Only $9.5 \%$ prepared a testamentary will and $80.3 \%$ did not want to prepare. More than half (59.4\%) of the subjects wished to spend the end of life at home; the remaining $14.4 \%$ at the hospitals; $4.3 \%$ at nursing facilities; $3.7 \%$ at other places; and $18.2 \%$ responded unknown (Table 5).

\section{Discussion}

This study figured out the physical, mental, social status, and thoughts of end of life of the elderly people living alone on the island of Kure city. A certain percentage of the subjects had abnormal signs and symptoms, which are easy to detect. For this vulnerable population, early detection and intervention such as disease management, nutrition support, and human support are necessary. The findings of this study will facilitate the municipal government to predict the burden and provide required care for these elderly people. The public health nurses can conduct regular home visit to identify and provide self-management education to the patients and connect with the primary care physicians for any illness.

About half of the subjects had high blood pressure with a higher percentage of grade I. There were other symptoms of arrhythmia (18.9\%), tachypnea (3.4\%), and more than half of them (52.9\%) had pedal edema. It is alarming that, they had also the history of cardiovascular diseases (18.8\%) with the risk factor of dyslipidemia (18.2\%). Most of the subjects suffered from physical pain. Knee and low-back pain can be triggered by accidental fall and many of them used auxiliary tools for their walking. Approximately $36.3 \%$ of the subjects had malnutrition and also had risk of malnutrition, which was significantly higher than the low nutrition ratio of Japanese aging people, 2\% to 14\% [16] [17]. Additionally, the immune function also can decline, which increases the susceptibility to infectious diseases commonly pneumonia. Mortality from pneumonia in Japan is the third-leading cause of death [18]. Therefore, the improvement of malnutrition is an important measure among aging people to hinder the need for long-term care. For elderly living alone, the number of meals decreased due to malfunction of body mechanisms and troublesome, the same drift also reported as a decrease in dietary intake and nutrition tends to be biased from a long-term viewpoint [19]. In addition, most of the subjects had the denture, and $8.4 \%$ had no teeth or defective teeth. Recent studies reported that when the teeth were missing, and the prosthesis were not worn, elderly people not able to intake nutrition sufficiently and ultimately deteriorating their health condition [20] [21]. Continuous low nutrition leading to lower physical strength and decreased activities and increasing the risk of bedridden [22]. Municipal government needs to be established nutritional support program for the elderly people. Existing public health nurses and nutritionists can provide nutrition education and food supplements.

Ultimately, patient may develop dementia [23] and there is a high-risk [24] to 
deteriorate the quality of life [25]. It could be prevented at the community level by early detection and proper management [26]. Regarding the mental state, $15.6 \%$ of subjects responded unhealthy and in the previous studies, it was $26.8 \%$ [27] and $24.6 \%$ in the regional cities in Japan [28]. The self-perception of the subjects [29] was healthy regardless of disease or disability. It is the important psychological function that subjective health sense is high due to living alone. On the other hand, more than half of the elderly people had worries and anxieties, and about half of them were concerned about their own health. Their worries were simple, such as accidental fall and incontinence when going outside. We can provide professional support to take care of these physical and mental conditions. Collaborating with the municipal government, disease management nurses or nurses at primary care clinics can provide telenursing and telemonitoring systems for monitoring vital signs and to manage any abnormalities.

The anxieties are not only causing a feeling of lowering health quality but also may affect depression tendencies, which had of $9.1 \%$ subjects. The elderly people those living alone were supposed to have a slight depression tendency [30]. It is considered that the deterioration of depressive symptoms is difficult to understand, and support of others is essential. The tendency of depression is strongly related to a subjective sense of wellness [29]. The risk of death of those who responded that subjective sense is unhealthy will be higher than those who positively answered [8]. As a result, the efforts in a region with a sense of security that can quickly find and respond to strengthen the system, so that subjective health feeling can be kept high. There were $15.0 \%$ of dementia patients in Japan [31]; however, 5.9\% subjects had declining cognitive function in this survey. Dementia was the most common in the elderly people, followed by cerebrovascular diseases [32]. It has been reported that the onset of Alzheimer's type dementia is eight times higher when living alone and inclines to the homebound tendency [33]. It is considered that the occurrence rate of homebound is about $10 \%$ to $15 \%$ in the elderly people aged 65 or older and exceeds $20 \%$ over 75 years old [14]. In this study, most of the elderly people had emergency contact persons and surrounding supports in daily life. As a result, it is needed to aware family members, relatives and other members for prompt detection of dementia and withdrawn and take necessary initiatives. However, a certain number of subjects had neither emergency contact nor surrounding support. Therefore, municipal government needs to introduce these people to proper support. In addition, the daily monitoring system is needed, since this very vulnerable population once something occurs; they are taken to the hospital and never come back home and die at the hospital.

Although, the long-term care insurance exists in the health care system, the elderly alone people still mostly depended on their children, relatives, primary care doctors, neighbors, and friends. Elderly people of $75.1 \%$ had the knowledge about long-term care insurance system, and many people did not know about the insurance procedures and services available in the study area. In a study 
found that about $60 \%$ of the family members knew about the insurance system [34]. Therefore, it is necessary to establish a comprehensive approach to provide knowledge to the elderly people and their consultation partners on information about services and the procedures of insurance system. Moreover, management connecting the long-term insurance service by engaging community or primary care nurses needs to identify and include the elderly people who are out of services. Elderly people need to be encouraged to participate regularly in the annual health check up that cost covered by the municipal government.

Approximately, 59.4\% study subjects wanted to spend their end of life at home, similar (54.6\%) finding was reported in a preceding survey; however, their age range was 55 years and older [4]. Subjects of $89.5 \%$ wanted to die without bothering anyone, comparable to the national data where it was found that about half of people did not want to ask the family members for their necessary treatment [35]. Around half (44.8\%) of the subjects wanted natural death without medical treatment, and $44.3 \%$ wanted to spend rest of their life with family and friends. Only $19.7 \%$ intended to prepare the last will testament. Although $59.4 \%$ subjects wanted to die at home, $47.7 \%$ believed that police would come due to the lonely death, for that reason $29.2 \%$ wanted to admit in the hospital before dying.

\section{Conclusion}

Majority of the subjects had some physical, mental and social difficulties. It needs special attention to support the elderly people within the community system. Although Japan is a developed country, malnutrition exists among the elderly people that need to be considered. We believe that it is necessary to provide information on correct recognition and long-term care insurance services in a manner appropriate to each elderly involving family, friends, relatives, community and government supporting staff for proper care of these elder people. Dissemination of knowledge and educate community people about the available care services and how to use them effectively to prevent any impending adverse and serious events. This study figured out that creating opportunities for preparing and thinking about advance care planning including their families.

\section{Acknowledgements}

We would like to express our deepest gratitude to the Department of Health and Social Welfare, Kure City municipality who provided the support for this study. We are also indebted to the staff and students from Hiroshima Bunka Gakuen University, Madoka Kawai, Mie Fukushima, and community people of Akinada district, Kure city who participated in this study. This study was funded by Kure city municipal government.

\section{Conflicts of Interest}

The authors declare that they have no conflicts of interest. 


\section{References}

[1] Ministry of Internal Affairs and Communications (2015) Elderly People over 65 Years Old in Japan Following Respect for the Aged Day. Chapter 90.

http://www.stat.go.jp/data/topics/pdf/topics90.pdf

[2] Ministry of Health, Labour and Welfare (2015) Report on Elderly Care Workers' Group. Elderly Care for Establishment of Care That Supports the Dignity of Elderly People. http://www.mhlw.go.jp/topics/kaigo/kentou/15kourei/3.html

[3] Ministry of Health, Labour and Welfare (2017) For Realization of the Integrated Community Care System, Chapter 1.

http://www.mhlw.go.jp/stf/seisakunitsuite/bunya/hukushi_kaigo/kaigo_koureisha/c hiiki-houkatsu/

[4] Cabinet Office of the Government of Japan (2012) Survey on the Health of the Elderly People.

http://www8.cao.go.jp/kourei/ishiki/h24/sougou/gaiyo/pdf/kekka_1.pdf

[5] Ministry of Health, Labour and Welfare (2016) Report on Health, Labour and Welfare. http://www.mhlw.go.jp/wp/hakusyo/kousei/16/

[6] Ministry of Health, Labour and Welfare (2015) Outline of Investigation of the Cost of Long Term-Care Insurance, 2015.

http://www.mhlw.go.jp/toukei/saikin/hw/kaigo/kyufu/15/index.html

[7] Yoshida, D., Ninomiya, T., Doi, Y., Hata, J., Fukuhara, M., Ikeda, F., et al. (2012). Prevalence and Causes of Functional Disability in an Elderly General Population in Japan: The Hisayama Study. Journal of Epidemiology, 22, 222-229. https://doi.org/10.2188/jea.JE20110083

[8] Okado, J., Bin, A., Tomoyama, G. and Hoshi, T. (2003) A Follow-Up Study on the Relationship between Subjective Health and Mortality among the Elderly People. Japanese Journal of Health Education and Promotion, 11, 31-38.

[9] Watanabe, M., Watanabe, T., Matsuura, T., Higuchi, Y., Shibutani, T., Usuda, K. et al. (2007) Predictors of Housebound among Elderly Persons Living Independently in a Rural Community. Nihon Ronen Igakkai Zasshi, 44, 238-246. https://doi.org/10.3143/geriatrics.44.238

[10] Kure City Official Website (2017) Population Data (Basic Resident Register). https://www.city.kure.lg.jp/soshiki/36/people.html

[11] Hiroshima Prefecture Official Website (2016) Annual Statistics of Population Dynamics in 2014. Book Number 43. Deceased Persons, Sex and Age, Statistics Table 11 . https://www.pref.hiroshima.lg.jp/site/toukei/26-jinnkoudoutaitoukeinennpou.html

[12] KouseikagakuKenkyujo Research Institute of Health Science, Inc. Longevity Science Integrated Research CGA Guideline Research Team (2012) Guidelines for Comprehensive Geriatric Assessment. 14.

[13] Kanda, S. and Kuzuya, M. (2012) KouseikagakuKenkyujo Research Institute of Health Science, Inc. Guidelines for Comprehensive Geriatric Assessment. 1st Edition, Assessment of Malnutrition. Relation to Gerontological Syndrome Assessment Chapter 5, Subheading 6, 218-225.

[14] Ministry of Health, Labour and Welfare and Housebound Prevention and Support Manual Sharing Research Team (2009) Homebound Prevention and Support Manual (Revised Edition). http://www.mhlw.go.jp/topics/2009/05/dl/tp0501-1g.pdf

[15] Center for Quality Assessment and Improvement in Mental Health (CQAIMH) (1999) Overview of the Patient Health Questionnaire 2 (PHQ2). 
http://cqaimh.org/pdf/tool_phq2.pdf

[16] Sakai, R., Yamada, S., Nima, Y., Hamasaki, T., Dewake, N., Ansai, T., et al. (2014) Relation between Nutritional-Health Status and the Current-Past Medical History in Elderly Outpatients. Journal of the Japan Dietetic Association, 57, 28-37.

[17] Kai, K., Kai, Y., Omi, N., Kuno, K. and Seiji, S. (2013) Study of the Use of Estimates BMI of the Elderly of Mini Nutritional Assessment-Short Form Screening. The Journal of Japanese Society for Parenteral and Enteral Nutrition, 28, 325.

[18] Ministry of Health, Labour and Welfare (2016) An Overview of Population Dynamics Monthly Reports. http://www.mhlw.go.jp/toukei/saikin/hw/jinkou/geppo/nengai16/

[19] Hirokawa, N. (2014) Geriatric Nursing. Society Surrounding Elderly People. Mizuno, T. Chapter 3. Family Forms and Social Problems; Subheading 4, 102-103.

[20] Kanehisa, Y., Yoshida, M., Taji, T., Akagawa, Y. and Nakamura, H. (2009) Body Weight and Serum Albumin Change after Prosthodontic Treatment among Institutionalized Elderly in a Long-Term Care Geriatric Hospital. Community Dentistry and Oral Epidemiology, 37, 534-538. https://doi.org/10.1111/j.1600-0528.2009.00496.x

[21] Torisu, T. (2017) Effects of Tooth Loss and Lowered Oral Function on Health Condition of Elderly People. Annals of Japan Prosthodontic Society, 9, 285-290. https://doi.org/10.2186/ajps.9.285

[22] Yoshida, S. (2017) Twenty Approaches That Do Not Make the Elderly People Malnourished. Dangerous Relationship of Elderly People with Low Nutrition. Medicus Shuppan Publishers Co., Chapter 1, 24.

[23] Shigetomi, T., Asano, T., Katou, T., Usami, T., Ueda, M. and Kawano, K. (1998) A Study on Oral Function and Aging: An Epidemiological Risk Factor for Dementia. Journal of the Japanese Gastroenterological Society, 47, 403-407.

[24] Yoshida, M., Nakamoto, T., Sato, Y. and Akagawa, Y. (1997) The Influence of Missing Teeth on the Satisfaction of Daily Living for Elderly People: A Questionnaire for the Elderly at Kure City in Hiroshima Prefecture. Japanese Journal of Gerontology, 11, 174-180.

[25] Shimazaki, Y. (1996) Follow-Up Study of Elderly Residents in the Facility on the Influence of the Condition of Teeth and Dentures on Health. The Journal of the Kyushu Dental Society, 50, 22.

[26] Baba, M. and Une, H. (2005) An Epidemiological Study of the Relationship between the Number of Remaining Teeth and the Disabled Elderly Receiving Long-Term Care. Nihon Ronen IgakkaiZasshi, 42, 353-359. https://doi.org/10.3143/geriatrics.42.353

[27] Hayashi, S. (2014) A Study on the Preventive Long-Term Care of the General Elderly Population Living in the Rural Area and Residential Estate of Town A. Bulletin of the Japanese Red Cross Hiroshima College of Nursing, 14, 103-111.

[28] Ikeda, S., Ueki, S., Shiba, Y., Niino, N., Watanabe, S., Sato, M, et al. (2017) Characteristics of Factors Affecting Health in Elder Adults Requiring and Not Requiring Support or Long-Term Care. Japanese Journal of Gerontology, 39, 341-351.

[29] Mitoku, K., Takahashi, T. and Hoshi, T. (2006) Health Relation Factors of Elderly People and Subjective Feelings of Health. Kawasaki Medical Welfare Journal, 15, 411-421.

[30] Yamashita, K., Kobayashi, S. and Tsunematsu, T. (1991) Depressed Mood and Subjective Sensation Well-Being in the Elderly Living Alone on Oki Island in Shimane 
Prefecture. Nihon Ronen IgakkaiZasshi, 29, 179-184.

https://doi.org/10.3143/geriatrics.29.179

[31] Abinet Office of the Government of Japan (2016) Report on Aging Society. http://www8.cao.go.jp/kourei/whitepaper/w-2016/html/zenbun/index.html

[32] Ministry of Health, Labour and Welfare (2016) The Overview of Comprehensive Survey of Living Conditions in 2016.

http://www.mhlw.go.jp/toukei/saikin/hw/k-tyosa/k-tyosa16/index.html

[33] Ministry of Health, Labour and Welfare (2009) Dementia Prevention and Support Manual Sharing Research Group. Dementia Prevention and Support Manual (Revised Edition). http://www.mhlw.go.jp/topics/2009/05/dl/tp0501-1h_0001.pdf

[34] The Dai-ichi Life Insurance Company (2015) Anxiety and Knowledge about the Experience and Care of the Family of Long-Term Care. Report on Life Design 2015. http://www.dai-ichi-life.co.jp/company/news/pdf/2015_060.pdf

[35] Ministry of Health, Labour and Welfare. Investigative Commission of Attitude Survey for End of Life Care (2014) The Report of Attitude Survey for End of Life Care Support. http://www.mhlw.go.jp/wp/hakusyo/kousei/16/dl/1-02.pdf 